\title{
WISH YOU WERE HERE; A SHORT HISTORY OF NEW ZEALAND MUSLIMS AND INTEGRATION
}

\author{
Abdullah Drury \\ University Of Waikato Islamic Studies Group, New Zeeland \\ abdullah@xtra.co.nz
}

Received: 10-10-2020

Revised: 20-10-2020

Accepted: 25-10-2020

\begin{abstract}
The recent court case of the Australian terrorist responsible for murdering 51 worshippers inside two mosques in Christchurch, New Zealand, has focused attention on this South Pacific nation. Nation-building, with its inherent practices of inclusion and exclusion into the social hierarchy, began here in the nineteenth century and accelerated throughout the twentieth century. History of Muslims in New Zealand, or New Zealand Islam, is a rich narrative illustrative of tendencies and biases that are both common to, as well as divergent from, patterns elsewhere in the English speaking world and Western societies in general. The integration of Muslim immigrants and refugees, and converts to Islam, into this complex social bricolage, however, has been challenging and at times convoluted. This essay will support us to consider why and how this is the case.
\end{abstract}

Keywords: Islamic Histoty, Muslims New Zealand; Integration.

\section{INTRODUCTION}

In March 2019 an Australian terrorist killed 51 Muslims attending prayers inside two mosques in Christchurch, the largest city in the South Island of New Zealand. In August 2020 his court trial too place and the miscreant was sentenced to life imprisonment with no parole. The incident raised many questions about social integration in this small South Pacific country and in particular, the integration of conventional and essentially well-adjusted ethnic and religious minorities unfamiliar with the prevailing socio-political system. Modernity is complex and can sometimes be quite ugly as secular polities are predicated entirely on the values and driving philosophies of the industrial revolution; in short, they are characterised by manifold flaws ${ }^{1}$.

The British scholar Ernest Gellner defined a nation as an 'anonymous, impersonal society with mutually substitutable atomised individuals held together above all by a shared culture. ${ }^{2}$ Precise notions and practices of integration remain ambivalent and nebulous, and worldwide no psychologically plausible programme for this transformation has been appropriately articulated; political speeches and reports on the topic have been as flowery and

1 Douglas Pratt, 'Antipodean Angst: Encountering Islam in New Zealand', Islam and Christian-Muslim Relations 21, no. 4 (1 October 2010): 397-407, https://doi.org/10.1080/09596410.2010.527107.

2 Anthony D. Smith, 'Book Review: Ernest Gellner, Nations and Nationalism (Oxford: Basil Blackwell, 1983, 150pp., f12.50 Hardback, f4.95 Paperback)', Millennium 12, no. 3 (1 September 1983): 280-82, https://doi.org/10.1177/03058298830120030804; Ernest Gellner, Nations and Nationalism (Cornell University Press, 2008), 57. 
ephemeral as the lyrics from a tune by the Cocteau Twins. In New Zealand, despite many asinine and banal political speeches about the positive features of 'multiculturalism', an exact detailed-model of integration into the prevailing societal fabric has never been explicitly defined. ${ }^{3}$ Religious pluralism is not new to this country. From its inception as an Anglo-Saxon Protestant colony in 1840, Roman Catholics and Jews (and others) secured various gains down the years, mostly clearly symbolised by the establishment of a vague principle of socio-political secularity. In New Zealand, as in most Anglophone lands, legislation and disinterested theoretical speculation tended to valorise broad human rights and ethnic minority rights, without outlining a specific plan of national integration. The polity remained neutral, and it was widely assumed that the new immigrants and refugees would find a place within a society ${ }^{4}$. of their own accord and in their own time and manner. Group-based autonomy was assumed.

Methodologically, this essay brings together empirical data collected by the author predominantly over the past 25 years and an extensive range of secondary sources. Primary data consist of qualitative fieldwork conducted with Muslims living across New Zealand. It involved in-depth interviews with various male and female Muslims of various ages, ethnicities, social classes and protracted participant observation- including but not limited to conversations at Muslim Association meetings, mosque interfaith events, attendance of the meetings of Muslim student groups and so forth. I assume that lay Muslim believers are not merely passive recipients of collective identities and schemata of communal association. Instead, they are both actors and agents with the ability and desire to utilise such international networks and resources for their purposes and according to their existential definitions in the socially reshuffled new New Zealand.

Readers should be aware that, for obvious reasons of confidentiality, individual informants are seldom cited or quoted. Secondary sources include existing academic research, policy documents, government reports and statistics, and newspaper articles. Auckland Muslims account for over $60 \%$ of the total New Zealand Muslim population, and therefore, they represent the natural focus of this text. Whilst not every single reader will locate his or her own experiences in the accounts of this essay. The author asserts that his broader analysis does outline the history of the community and provides vital clues to the future social and cultural trends that cut across the experiences of the majority of the Muslim community in this land.

\section{HISTORICAL OVERVIEW}

An overview is in order.

The first Muslims to visit New Zealand were Asian sailors, lascars who worked on board European ships. The British colony of New Zealand was created over 1840-1841 when the Colonial Office sent Captain William Hobson to claim sovereignty and negotiate a treaty with the native Polynesian tribes. ${ }^{5}$ Established under Queen Victoria, the territory was briefly

\footnotetext{
${ }^{3}$ It is important to remember that a culture can be corrupted. A pathological obedience to dated customs and laws, resilient modes of thought, may appear expedient or proficient, but also ultimately it provides an illusory form of psychological safety.

${ }^{4}$ Corinne David, 'Divergence and Convergence in the New Zealand Bicultural Model', Caliban. French Journal of English Studies, no. 21 (1 May 2007): 57-66, https://doi.org/10.4000/caliban.1856.

${ }^{5}$ For an excellent introduction to the establishment of modern New Zealand, see: Paul Moon, This Horrid Practice: The Myth and Reality of Traditional Maori Cannibalism (Rosedale, N.Z. ; New York: Penguin Group, 2008);
} 
part of the British colony of New South Wales, Australia, until July 1841 when it became an independent colony. European, especially British, immigration increased and in 1852 a legislative chamber was voted in. From 1856 the colony was effectively self-governing in all domestic affairs, and in 1907 King Edward VII proclaimed New Zealand a Dominion within the British Empire. Forty years later, the nation adopted the Statute of Westminister, confirming loyalty to the British crown but total autonomy of the New Zealand parliament ${ }^{6}$. The first Muslim family to reside permanently arrived in 1854, when Wuzerah and his family left India and settled in Cashmere, in the Canterbury province, to work for Sir John Cracroft Wilson. Wuzerah was involved in transporting stone from the Port Hills to the (Anglican) Christchurch Cathedral when it was constructed in the 1880s. He died in 1902. From the 1890s onward men from the Punjab and Gujarat regions of India came to work across the country.

After the 1930s some of these men or their sons began to bring out wives and children. In 1950 the first Islamic organisation was created when the "New Zealand Muslim Association" (NZMA) was formed in Auckland, the largest city in the land. At the time there were around 200 Muslims in the entire country. ${ }^{7}$ In 1951 the MS Goya brought in dozens of Muslim refugees from Europe, including Albania and Yugoslavia. In 1959 the NZMA acquired a property for use as the first Islamic Centre and the following year Maulana Ahmed Said Musa Patel (1937-2009) arrived from the Gujarat to serve as the first official Mullah; for three decades he operated regular Quran classes and provided Islamic education in central Auckland. The Association erected the first purpose-built mosque in New Zealand over 19791980, in Ponsonby, central Auckland. Over the 1960s and 1970s there was a modest trickle of migrants, refugees and students who helped create new Muslim organisations in the regions outside Auckland. For instance, over 1962-1964 the Wellington-based "International Muslim Association of New Zealand" was created and in 1977 the "Muslim Association of Canterbury" in Christchurch. In 1979 there were around 2000 Muslims across New Zealand and representatives of the regional Islamic Associations assembled to form a new nation-wide Muslim organisation to co-ordinate communal affairs at a national level; in April 1979 the "Federation of Islamic Associations of New Zealand" was formed with MS Goya refugee Mazhar Krasniqi (1931-2019) as the inaugural president. ${ }^{8}$ This was a statement of power,

Stuart C. Scott, The Travesty of Waitangi: Towards Anarchy (Campbell Press, 1995); David Round, Truth Or Treaty?: Commonsense Questions about the Treaty of Waitangi (Canterbury University Press, 1998); Kenneth R. Minogue, Waitangi: Morality and Reality (Wellington, N.Z: New Zealand Business Roundtable, 1998); Richard Allen Epstein, The Treaty of Waitangi: A Plain Meaning Interpretation (New Zealand Business Roundtable, 1999); Erich Kolig and Nahid Kabir, 'Not Friend, Not Foe: The Rocky Road of Enfranchisement of Muslims into Multicultural Nationhood in Australia and New Zealand', Immigrants \& Minorities 26, no. 3 (1 November 2008): 266-300, https://doi.org/10.1080/02619280802528502; John Robinson et al., Twi\$ting the Treaty: A Tribal Grab for Wealth and Power (Tross Publishing, 2013).

${ }^{6}$ James Belich, Making Peoples: A History of the New Zealanders From Polynesian (Penguin Random House New Zealand Limited, 2007).

${ }^{7}$ New Zealand Census and Statistics Department, Population Census, 1951: Religious Professions, Including Summaries for Dependent Children, Race, and War Service (R.E. Owen, Government Printer, 1953).

8 Ainsley Thomson, 'Mazhar Krasniqi", New Zealand Herald, 2002, A6; Zohoor Mohammad and Krasniqi Mazhar Shukri, One Hundred Great Muslim Leaders of the 20th Century (New Delhi: Institute of Objective Studies, 2006), 157-60; Sabit R Abdyli, Bijtë e Shqipes Në Tokën e Reve Të Bardha (Auckland: Universal Print \& Management, 2010), 88-90; Bayer Kurt, 'Kaumatua' of Muslims in NZ Dies Aged 87”, New Zealand Herald, 2019, A19. 
autonomy and agency. In 1984 the Federation secured its first annual Halal meat contract with the New Zealand Meat Producers Board; henceforth New Zealand meat exported abroad was examined and certified to ensure it was Halal and acceptable for Muslim consumption. In 1982 Sheikh Khalid Kamal Abdul Hafiz (1938-1999) from India arrived to serve as Imam in Wellington, the capital. Over 1984-85 the Muslim Association of Canterbury erected the first mosque in the South Island, on Deans Ave in central Christchurch. According to the 2018 census there are presently 57,276 Muslims in New Zealand'.

In August 1992, several Muslim immigrant families and teachers grouped together to create the "Al-Madinah" primary school in South Auckland. Many were associated or linked to the Tablighi Jamaat organisation, which has its roots in the Gujarat, India. Later that year, in December, the school was fully registered with the state. In 1995 a secondary section was added to the extant school, to accommodate older pupils. The following year, the school was integrated into the official education system of New Zealand and now receives state funds. Presently, Al-Madinah has over 500 students and 30 staff. Another group of Muslim parents established the "Auckland Muslim School" in the early 1990s, elsewhere in the same city, but this project did not succeed and was closed by the end of the decade. In 2001, the Zayed College for Girls was created by folk associated with the Al-Madinah School after receiving funding from the United Arab Emirates. However, we must note that over the years there have been several complaints directed at the Al-Madinah school-largely over financial irregularities and staff recruitment. In May 2016 the New Zealand Education Ministry imposed a statutory manager; his report, the following year, revealed serious concerns about expenditure and compliance with New Zealand legislation regarding school management. In April 2019 the Ministry dissolved the school's board of trustees and appointed a commissioner for similar reasons.

Just as New Zealand identities have changed and recalibrated over time, so do have local Muslim identities. Over two hundred years ago, most New Zealanders were Polynesian tribesmen. A hundred years ago, following decades of Anglo-European immigration, most were Caucasian in genomes ${ }^{10}$. Over the past thirty years, from 1990 onwards, a significant minority of Asian and African groups have settled in the country. What has emerged alongside 'religious' Muslim identities in places like Australia and New Zealand are socio-political 'associational' identities, where increasingly self-identification of Muslims in New Zealand as Muslims reflects a complicated wider narrative of socialisation in New Zealand. This is a sociological dynamic that is not unique to the South Pacific and relates much to what individuals perceive and strive for within their own aspirations and capabilities. Perhaps unsurprisingly, recent research demonstrates that most New Zealand Muslims conceptualise and construct their ideas about integration and citizenship, their heuristic biases regarding

9 Abdullah Drury, 'Mahometans on the Edge of Colonial Empire: Antipodean Experiences', Islam and Christian-Muslim Relations 29, no. 1 (2 January 2018): 71-87, https://doi.org/10.1080/09596410.2017.1384230; William Shepard, 'NEW ZEALAND'S MUSLIMS AND THEIR ORGANISATIONS', New Zealand 8, no. 2 (2006): 37; William Shepard, 'Erich Kolig, New Zealand's Muslims and Multiculturalism. Muslim Minorities, 9. Leiden and Boston: Brill, 2010, vi. 272 Pp. ISBN 978900417835 9', Contemporary Islam 6, no. 2 (1 July 2012): 205-7, https://doi.org/10.1007/s11562-010-0143-6.

10 Shah Nister Kabir and Michael Bourk, 'Representing Islam and Muslims in New Zealand Newspapers', Journal of Muslim Minority Affairs 32, no. 3 (1 September 2012): 324-38, https://doi.org/10.1080/13602004.2012.727293. 
participation in the wider host society, on their own terms and according to their own priorities. These hermeneutical paradigms are usually above and beyond official government policy proclamations and idiosyncratic goals. These invariably correspond to their own education and comprehension of matters involved. ${ }^{11}$

There is a larger socio-political context for this and our starting point in History is Biology. ${ }^{12}$ How are decent and ordinary citizens transformed into heartless beasts accused of violence? The answer is not attractive. In fact it is very personal and for many, challenging. However, the answer is indicative of humanity and the degree to which we all subsume our souls within social conformity and consensus. However, if we think deeply and clearly conscientiously-there are inescapable conclusions. To begin with, human beings are biological organisms. We are all motivated by two compelling and fastidious biological impulses survival and reproduction. All History revolves around this Darwinian fact and these twin imperatives of natural selection. All past events can be explained by recourse to this science and any interpretation of history that ignores the basic human compulsion to live and reproduce, fails to adequately inform the reader. To survive, all social units collaborate and compete for resources. Humans have been undertaking this path for many millennia now and the evolutionary scientists argue convincingly that it is an integral part of our essential biology. Societal competition and cooperation leads to the rise of capable leaders and hierarchies: the most capable and competent individuals within any social unit rise to the top of the hierarchy, whilst the less able do not. Successful leaders pursue a path of prosperity through law, order and justice. However, this process necessitates some measure of discrimination in terms of the allocation of resources - the social group that treats all members absolutely equally over a long period of time (the achievers and under-achievers) will perish. The same, or similar, applies to social and political units. Those at the top of any given social order have better opportunities to find mates and choices with regard to reproduction. The levels of competition and discrimination can be fierce, unpleasant even. Aggression and incandescent rage is human; peace time is an opportunity to prepare for conflict. Long before testosterone became a subject of scientific study, Thomas Hobbes even simplified the concept down to an easily remembered Latin axiom: bellum omnium contra omnes (war of all, against all). ${ }^{13}$ Most anxieties about race and religion can be partly explained through this mundane theory. With regard to human biology, culture, neurology and physiology, we know that shared group activities foster a sense of collective group identity; group violence, directed at other 'outside' social units, equally fosters a deeply narcissistic sense of group identity, purpose and accomplice. Most modern societies and nations are a conglomerate of multiple overlapping hierarchies. Consequently, in summary, a complex network of interwoven hierarchies and social tensions are inevitable and ubiquitous.

Some folk will argue that such hierarchies are only social constructs, created intellectually by rigid ignominious political elites to govern other more malleable or pliable

${ }^{11}$ Shepard, 'Erich Kolig, New Zealand's Muslims and Multiculturalism. Muslim Minorities, 9. Leiden and Boston'.

${ }^{12}$ Charles Darwin, On the Origin of Species by Means of Natural Selection: Or the Preservation of Favoured Races in the Struggle for Life (D. Appleton, 1869).

13 Horst Bredekamp, Thomas Hobbes - Der Leviathan: Das Urbild des modernen Staates und seine Gegenbilder. 1651-2001 (Walter de Gruyter, 2012), 15. 
societal groups. This is either a partial truth or a perceptual rubric. The reality is that humans exist and function best in hierarchies. We have a nervous system finely attuned to status, one that revolves around levels of serotonin (a brain chemical mostly associated with feelings of happiness). The higher up a hierarchy a human clambers, the more this brain mechanism helps produce more serotonin. The more serotonin, the more personal happiness. Conversely, the more defeat and setbacks experienced, the lower the supply of serotonin. Lower levels of serotonin are frequently associated with negative emotions. There is no avoiding our desire for serotonin or our participation within some form of hierarchal structure(s). Unfortunately, since Karl Marx, we live an era when many folk believe that these hierarchies and forms of discrimination, this process of jostling disputes over dominance, are exclusively political and intrinsically ideological in nature; this is to argue that men only seek power and discriminate for its own sake, out of pure malice or the simple desire to tyrannise other social groups for their own personal gratification.

Dominance hierarchies may not seem very nice and they may not appear to be a polite manner in which to structure an idealised society. Proximity to authority and power leads to discussions about hegemony and a desire to influence decisions. To overpower or be overpowered that is the question. This point of vacuous bifurcation and cognitive dissonance hints at an agonistic ontological relationship. The uneven unhappy or unsatisfactory nature of any given dominance hierarchy is something fundamental to the nature of reality. It allows a disenchanted individual to become indifferent and numb to the suffering of others, those in classes or orders below our own. Only a small minority of individuals will ever preserve their moral autonomy intact and this may be at the cost of engaging in personal stratagems and patterns of behaviour that allow them to evade a sense of direct responsibility. However, a knowledge of biology and hierarchies provides a useful teleological framework for critically connecting together and evaluating the cumulative impacts of the human behaviour and psychology.

Capitalism and social hierarchies are sometimes brutal and heartless but equally very efficient and effective, especially in the reliable provision of produce and services. More importantly, humans cannot seriously re-structure society in a way that is radically at odds with our biology. The various utopian experiments of the last century (Socialism, Communism, Nationalism, Fascism and so forth) all failed horribly, violently. Ideological systems that ignore biological confluences and continuities will always fail. In our era, Feminism struggles to constantly re-assert itself because it posits an imaginary tyrannical patriarchy as a privileged class enemy and consequently spends much time tilting at windmills. In order to really understand the past, we need to comprehend that all human behaviour can be attributed to the survival and reproduction impulses and that the subsequent hierarchies are an inescapable part of this. Optimally, our minds are chemically rewarded and punished for our level of competence within any given hierarchy. On the flipside, the positive point here, is that humans can participate in several distant, related or overlapping hierarchies at the same time we compete and collaborate in multiple hierarchies and not just one huge one. This is a core feature and prime function of human biology and has been for centuries. It enables us to function in complex, evolving societies and nations. Unfortunately, in New Zealand at least, hyperbole and sensationalism draw attention and win votes. The success of the glutinous 
political Left-wing 'intelligentsia' in harassing this reality and the long term effects of their activism has been remarkable. ${ }^{14}$ Whilst many may have started with a genuine concern for minority groups and issues, much of the contemporary Left has morphed into a remarkable extremist lobby group accountable to no one person or agency, to no higher authority or reference point other than their own self-appointed 'committees of virtue' (to borrow the phrase from Dostoyevsky.) They actively create and foster problems attacking natural hierarchies predicated on hard work, talent or skill but offer no solutions beyond a narrow scope of concocted, unrealistic and often absurd ideological platitudes.

So our starting point in any analysis of New Zealand history and the topic of integration of the Muslim community is the point that the hyper-successful and productive folk are always a minority within any given social unit. Folk groups come into contact with one another, collide, coalesce, discriminate, disengage, and separate in corporeal reality. Hence the ongoing accusations of racism, bullying and favouritism a few of these are real in New Zealand, and deserve to be taken seriously, however most are facile or futile upon examination. The multidimensional forms of hierarchies can lead to an obsfuscation of reality and a promiscuity of the application of related terminology. For instance, in 2017 Rafik Patel wrote an academic essay exploring the migration of his forefathers from India to New Zealand in the 1910s. ${ }^{15}$ His account is a fascinating and well written one full of intimate detail, covering several decades of family experience. However, he repeats some minor anachronisms and historical errors. He produces no personal anecdotes from his own family to demonstrate episodes of racial discrimination, but he does mention several popular but fallacious assumptions 'misunderstandings' of New Zealand history. Until 1936, Patel indigently states, ethnic Indians in this country were not entitled to Social Welfare. This will come as a surprise to students of New Zealand legislative history: the Social Welfare Act was passed in 1935 and all New Zealand citizens were eligible. The idea that Indians were excluded before this date on the basis of race, or that the state charity was only granted to Anglo-Europeans, finds no reality in well-grounded history. It is easy, however, to see how the miscomprehension arose. Life exists only within the boundaries of communal tension and competition. Individuals may well 'sense' racial discrimination and jaundice when they are, in fact, simply experiencing this wider contest. ${ }^{16}$ The contingency of human existence inside this socio-political crucible directs

${ }^{14}$ Some individuals are unproductive and impoverished because they are incompetent or refuse to work. CulturalMarxists or Neo-Marxist intellectuals, and other such oscitant pseudologues, inform them the only cause of their poverty, suffering and discrimination is due to someone else another individual or social group and the resentful under-achievers will buy into this thesis quickly. (The alternative that they may be responsible for their own problems is always unpalatable.) If it can be suggested that the success of the others, the minority, is due to theft, then this thesis takes on a degree of virtue. To steal or confiscate from thieves is no moral crime in most societies - indeed, it may be a real moral obligation.

15 Rafik Patel, 'A Flowing Culture: Images of Early Gujarati Indian-Islamic Migrants in Aotearoa New Zealand', Transitions: Journal of Transient Migration 1, no. 2 (1 June 2017): 251-67, https://go.gale.com/ps/i.do?p=AONE\&sw $=$ w\&issn=23977140\&v=2.1\&it=r\&id=GALE\%7CA489081374\&si $\mathrm{d}=$ googleScholar\&linkaccess $=$ abs.

16 See: Katherine Hoby, 'NZ -land of milk and honey', Press, 10 December 1998, p.2. Tarek Abaza, a recent immigrant from Egypt, was interviewed in a Christchurch newspaper and commented on how wonderful the country was, except that he could not find employment to match his work skills. He commended the people and the environment of Canterbury but was at a loss to explain his struggles to get a foothold in the economy, in the society. He stated that, before immigration to New Zealand, he had been informed explicitly that it would be no problem for him to find a job. I would suggest that he had indeed been misinformed of his prospects in this country but I am at a loss to comprehend how he might have expected to walk into a new country and anticipate a top level job and a high ranking in the prevailing social status. 
that we are born into one social unit or another, into one side of any given dispute or tension. Although precise social borders may be somewhat fluid, we cannot really select our ethnicities; nor can we choose the corporate body - the nation or nationality - to which we might prefer to belong. The question of whether our social unit is the ethically or morally "good" one is entirely moot. Even when the collective memory of communal myths and legends is undertaken by Historians and is tracked into some distant past to demonstrate the moral high ground, to capture or emphasise the moment of folk group or class unity, it transpires that the horizon keeps waning and the accomplishment loses its lustre. There is no escape from the history of social tensions and hostilities, the empirical reality is overwhelming. However, it is vital that such tension and hostility be confined and converted to forms of cooperation if it is not to dissolve society itself or destroy the land in endless warfare; such tension can expand only within specific limitations. ${ }^{17}$ There is no real synthesis - the appearance of synthesis is invariably the triumph of one side, one faction, in the contest. (The conqueror may well indeed adapt or adopt aspects of the conquered but one should not be deceived by appearances.)

\section{THE THEORY AND PRACTICE OF INTEGRATION}

The previous section focused on the manner in which biology situates history and human behaviour at the interface of our cognitive limitations and contextual circumstances. The idea - and ideal - of peaceful integration into the prevailing social hierarchy remains at the core of New Zealand notions of multiculturalism. Nation building, with its inherent practices of inclusion and exclusion into the nebulous social hierarchy, began here in the nineteenth century and accelerated throughout the twentieth century. It is closely tied to idea surrounding societal cohesion and labour division. ${ }^{18}$ For instance, during the 1999 Kosova crisis, the New Zealand government agreed to accept hundreds of refugees. Albanians in Auckland received them arriving at the airport and on one occasion Mazhar Krasniqi, a former president of both the New Zealand Muslim Association and the Federation of Islamic Associations, welcomed them a short speech:

You are lucky ... New Zealand guarantees you all the rights. There is law here ... there is no discrimination here. You have double responsibility, as Albanians and citizens of Zealand. Here you will be respected and welcomed ... together we will overcome all the difficulties. ${ }^{19}$

Clearly the Albanian Muslims did not perceive New Zealand to be a land of ubiquitous racial oppression or systemic tyranny, but they did anticipate the challenges inherent in migration and integration into another society.

The terrorist attack on the Christchurch mosque highlighted the real and perceived tensions in New Zealand multiculturalism and societal integration as an objective. As with the

17 Sometimes the immigrants and refugees see this more clearly than others. In 1998, Abdurahman Jama Osman, a Somali refugee turned community leader, complained to a Wellington newspaper that refugee agencies were encouraging immigrants and refugees to 'concoct complaints' about various issues - such as employment - in order to secure more government funding for their own activities. The agencies concerned firmly disagreed, naturally. Osman asserted categorically that there was no job discrimination and 'no enmity with the New Zealand people.' See: Tom Cardy, 'Somalians told to complain, says community leader', Evening Post, 29 April 1998, p.19.

${ }^{18}$ Erich Kolig, New Zealand's Muslims and Multiculturalism (Leiden: Brill, 2010).

${ }^{19}$ Sabit R. Abdyli. Bijtë e shqipes në tokën e reve të bardha (Auckland: Universal Print \& Management, 2010), p. 69. 
11 September (2001) terror attack in the USA, it seemed to highlight Samuel Huntington's provocative sketch of a permanent 'clash of civilisations' between the East and West, between the world of Muslims and the world of Christians or 'the West'. A large coterie of academics, journalists and politicians has articulated an interest in the Huntington thesis, one way or another, and the exact position of Muslims and Islam inside Western societies. The United Kingdom of Great Britain plays a curious role in these discussions. Historically the British Empire governed millions of Muslims during the colonial era, and indeed many of the earliest Muslim settlers in New Zealand came through those lofty channels from British India. However the critical aspect that had transformed former subjects of a cosmopolitan empire into full citizens is the established presence of Islam in most New Zealand urban centres. Presently, with over 50 mosques and Islamic centres, plus various special spaces for Islamic prayer across the land (on university campuses and so forth), Muslim immigrants and refugees have made New Zealand their new home. Former colonial subjects, lascars, itinerant hawkers and sojourners have transformed into acknowledged citizens. They have introduced a distinctive Islamic character to some suburbs, with Islamic dress hijabs and skullcaps - no longer an unusual feature of the social landscape. Muslims can now be found in every statistical district.

However, the internal diversity of the Muslim minority in New Zealand today does make it problematic to write about a specific singular 'Muslim community'. Is it pragmatic or superfluous to discuss the Muslim community here as a coherent totality? The daily realities in which New Zealand Muslims live are complex, diverse, fluid and porous. Such a facetious tack will homogenise the experiences and views of individual actors who differ enormously along ethnic, linguistic, gender, national, political and theological lines. An overly simplistic image of a singular monolithic 'Muslim community' ignores the reality of clusters of single individual agents competing and/or cooperating within multiple hierarchies across variant socioeconomic configurations; complex forms of spirituality are compressed into political theatre. While, presently, most New Zealand Muslims are ethnically 'Asian', a significant number are 'Arab' (either African or Middle Eastern) or sub-Sharan African, especially Somali. Less than half were born in New Zealand, although a significant number hail from Fiji. There are a substantial number of local converts to Islam drawn from the indigenous (Maori) population or the Anglo-European (Pakeha) population. Intermarriage, especially across generations, makes accurate categorisations increasingly difficult. For instance, according to the 2013 census, there were 4,353 Muslims among the Anglo-European population; this adds up to approximately $9.5 \%$ of the total Muslim population figures (so, almost one in ten New Zealand Muslims may be classified as 'European'). ${ }^{20}$ However most of these are married to immigrants of differing ethnicity, nationality and so forth. What category to their children fill? Furthermore, Muslims in New Zealand affiliate across several Islamic spiritual and theological sub-groupings, denominations and Mazhab (schools of legal thought). Most are Sunni but there are vocal Shia community groups. Overall the Muslim community includes active members of various Ahmadiyah, Salafi and Sufi expression of faith.

${ }^{20}$ Libby Libson, 'Kiwi Converts among New Zealand's Muslim Community', Stuff, 13 November 2015, https://www.stuff.co.nz/life-style/life/73973867/kiwi-converts-among-new-zealands-muslim-community. 
Naturally, there are significant differences in how religiosity and confessional practice is conceptualised and undertaken by individuals. The personalised feature of religiosity in the modern era, especially in New Zealand, suggests a departure from custom and tradition where robust spiritual experiences and religious proclivities were mediated by shared, collective activities (in the form of a faith that is specifically communal in orientation or highly institutionalised by state agencies for example ${ }^{21}$.) In an existential sense, being Muslim in a Muslim minority context does not end with an inveterate religious identity in Islam alone. Rather, being Muslim is typified by variant articulations and manifestations of identity and multifaceted kinds of individualised processes of spirituality and religiosity that help individual Muslims to make sense of the world around them (through lectures, literature or online activities.) The obvious sociological and historical complexities inherent in describing and designating a collection of folk tied by faith, ethnicity or any other type of similarity cannot be underestimated. Attaching a default spiritual or theological identity to all members of all Muslim communities is particularly problematic in New Zealand and risks onedimensional reification and injudicious myopia.

Whilst academics and researchers should not underestimate or misjudge the subjective permeability and subtle nuances that typify a social aggregate like the New Zealand Muslim community. ${ }^{22}$ I suggest that a broadly shared set of core spiritual and religious beliefs does make it meaningful to study New Zealand Muslims as a distinctive and holistic social grouping. We must avoid the monomaniacal postmodernist trend to dismiss such complexities as a mere discursive construction. The tyranny of social hierarchies evolve slowly and oblige individuals to retreat-morally-incrementally. However, every such retreat betrays the conscience and only serves to increase the probability of another; every rationalisation reduces resistance and serves to increase the probability of further tyranny. (This is especially marked when some individuals gain from such steps ${ }^{23}$.)

Under these circumstances, the Muslim communities of New Zealand - in view of their small numbers, economic status and intrinsic internal ethnic and linguistic diversity have not actively participated in the wider processes of nation-building in this country but they have been present within the prevailing, evolving societal hierarchy. If anything, Muslim leadership has mostly resisted nationalism and parochialism, advocating instead for an amenable, universalist conceptualisation of the faith and a collectivist organisation of all believers. This has contrasted with popular atheist and secularist tendencies towards the nation-state. This has proved challenging for integration but not impossible. The absence of a clear strategy for the inclusion and integration of Muslims has allowed non-Muslim political leaders much wiggle room to negotiate societal boundaries and ideas revolving around the collective identities contained within the polity. Compassion slides into contrivance. The most

${ }^{21}$ Ahmad Hidayat Buang, 'Islam and Muslims in New Zealand', Jurnal Usuluddin 16 (2002): 135-158.

22 'Islam in New Zealand', in Wikipedia, 27 October 2020, https://en.wikipedia.org/w/index.php?title=Islam_in_New_Zealand\&oldid=985791976.

${ }^{23}$ Khairiah A. Rahman and Azadeh Emadi, 'Representations of Islam and Muslims in New Zealand Media', Pacific Journalism Review: Te Koakoa 24, no. 2 (2018): 166-188; Sue Middleton, 'Becoming PBRF-Able: Research Assessment and Education in New Zealand', in Assessing the Quality of Educational Research in Higher Education (Brill Sense, 2009), 193-208. 
significant components in this direction have been institutions such as governmental relationships with minorities and public education.

\section{MUSLIMS IN NEW ZEALAND: AN INVISIBLE HISTORY}

The nefarious events of March 2019 in Christchurch - as with those of 11 September 2001 in the USA, Madrid in 2004, London in 2005, Paris in 2015, Brussels, Nice and Orlando in 2016 - have distressed, ruptured and mutated Muslim-Western societal relations. To reverse the observation by Ernest Gellner about nations and nation-building, what once resembled a painting by Amadeo Modigliani now looks like one by Oskar Kokoschka ${ }^{24}$. The weird threat and Nietzschean abyss posed by the cognitive bias of violent jihadists and Western policies against terrorism (not to mention foreign interventions in the Muslim countries) have all served to polarise social attitudes regarding ideas about Muslim integration and the monotheism of Islam. Under such auspices, widespread suspicion about cultural 'diversity' abound everywhere men think and it can be said to provide a certain measure of naïve psychological security. Certainly both academic and non-academic agents have responded to the real and perceived fears of terrorism, whether Muslim or otherwise. In the decade following September 11, there was a marked increase in literature on Islam, Muslims and terrorism in all languages. Various aspects and features of the Islamic faith have been studied and analysed with a microscope. This has also initiated overdue research on the contemporary place of Islam within Western societies such as New Zealand. Some of the new literature has been of poor quality, some masterly. In our era, both academic and lay readers have no few excuses to explain their ignorance of the social history and settlement of Muslim communities in Western countries.

It is easy and tempting to contemplate the past as an overarching meta-narrative of saints and sinners, cowboys and Indians, but that serves as propaganda, not serious History. Even when we read literature of quality Dickens, Dostoyevsky, Selimovic, Shakespeare the ongoing moral struggles are never between pure evil and pure good; the best reading material reflects upon the reality of the complicated, incongruent and often enigmatic conflicts between individuals trying to cope with a life that proffers both aspects. The temptation to allocate all virtue and all evil to one side or another is unrealistic and such an approach only appeals to unreliable ideologues seeking to supplant the truth of life with their own utopian agenda (often of semi-Marxist provenance). If we agree that some kind of deep introspection is needed to secure genuine moral progress then we must avoid the allure of oversimplification in History.

Muslim community leaders have long been aware of this convoluted problem. For instance, some years ago a local convert to Islam named Nizam Flynn wrote in a regional Muslim newsletter:

Our community is made up of number coming from various parts of the world, people coming from many different backgrounds and bringing with them many diverse cultures. In general, similar events may be handled in a different manner when the event takes place in another part of the world. To understand one anothers culture

\footnotetext{
${ }^{24}$ Gellner, Nations and Nationalism, 139-40.
} 
is very important when a multicultural society or community is trying to establish unity or trying to form one community. It is very easy and to a certain extent natural that splinter groups will arise within a community when its members try to impose their own cultural ideas on others in matters concerning mutual community affairs..... By the same token, a particular grouping should not lose their composure if their suggestion is not adopted by the Shura ${ }^{25}$.

In Australia, academics have produced excellent analyses and studies of the local Muslim communities and their histories. These educational resources have been buttressed by a thin quasi-professional material supplied by various media (newspapers, television, radio and so forth.) This nexus point all adds up to a form of interdisciplinarity that combines questions of efficacy with broader questions of ethics and purpose. Unfortunately, in all honesty, the experiences of New Zealand Muslims have been consigned to the more obscure corridors of academia. A faith that garners the affiliation of only $1 \%$ of the population has been mostly invisible to scholars studying New Zealand history. Most of the existing academic corpus on Muslims in New Zealand relies on research of three or four academics, all operating in Anthropology and Religious Studies: Dr William Shepard, Dr Erich Kolig and Dr Jacqueline Leckie. (A pertinent reminder of the tendency of secular and atheist New Zealand society in general to marginalise religion and religious experiences. It is also extraordinarily germane that none are Muslim.) These three have proffered significant contributions to public education and the comprehension of New Zealand Muslim identity, community and cultural negotiations, albeit with an almost exclusive focus on the Asian element of the minority. Little of the literature currently in circulation expresses an in depth history of the New Zealand Muslim community and their integration issues or indeed a specific perspective on Muslims qua Muslims in New Zealand. In light of the increasingly instrumental place of Islam (however defined) within both the Muslim communities themselves and the wider society, a concurrently historical and holistic view of Muslim history in New Zealand is long overdue. The markedly New Zealandish stories recounted by several newspapers concerning local Muslims following the March 2019 shootings, ought to be supplemented with a thorough analysis of the history of the wider Muslim communities. New Zealand is a society that has often been romanticised as some kind of social justice paradise, however the Darwinian reality has always been more complex, less sanguine. This essay gives a voice to these historical experiences.

Underneath our cognitive and social architecture, is a layer of symbolic and dramatic narrative representation that instantiates the same ideas and ideals but within a multidimensional and multifaceted context. Religion provides a rich mode of power that an appeal to human reason cannot seriously match, and brings art, architecture, music, literature and basic societal organisation to all humanity. Over time, religion and faith act as a bulwark or a buttress-a cognitive structure against the various forces that would produce chaos and destroy society from within.

25 Abdullah Drury, Islam in New Zealand: The First Mosque: A Short History of the New Zealand Muslim Association \& the Ponsonby Mosque (A. Drury, 2006). 
The processes and relations of integration - identity and identification in particular are never static. To start with, identification is a complex intra-subjective process that involves drawing distinctions-that is to say, a selective choice of particular cultural aspects and features with the aim of fostering specific identity. In many respects, the objectivity of identity and integration is then partially an intellectual abstract or construct, but partially a reflection of a concrete empirical reality. The intellectual aspect remains a subjective experience, an imagined reality. We must bear in mind that New Zealand society has always been a complicated bricolage of segments drawn from diverse ethnic, class, confessional and cultural origins. Denying the biological context within which behavioural affairs are governed or conducted then closes off core moral discourses and reduces the scope within which actors can determine or discern the role of forces shaping observed behavioural patterns. The myth of monoculturalism and social homogeneity is a popular idea for nation-states but is not predicated on reality. There is a need for further education and a better comprehension of this history of mutual interaction and tolerance in modern New Zealand in order to avoid conflict, build consensus and negotiate compromise. This must be the wiser move for the integrity of society.

Ultimately, the emerging connections that can be made between Biology and History and our comprehension of irrationality, social hierarchies and levels of discrimination - signal critical contributions that science can make to the analysis of the past. These are contributions that not only draw attention to emerging studies on the patterns of human thought and behaviour, but also the boundaries of rationality. To these ends, Biologists can undertake a significant role in exposing the arbitrary assumptions related to reason that flow from social discourse.

\section{CONCLUSION}

Modern New Zealanders are not a nation drawn from a singular source but instead a spectrum of semi-independent/confederal social units (one might almost write 'tribes') with similar but differing cultures and language skills. The absence of an academic book on the history of New Zealand Muslims constitutes a curious lacuna in the growing corpus of scholarly literature examining the development and integration of Muslim communities in the social hierarchy of this country. The main objectives of my essay were to address this omission and to provide some sort of account. The meaning of this history has been shaped by both the domestic and global shift in public attitudes towards Muslims and infused by the cultural, social and political means of relating to religious minorities, diversity and integration that are peculiar to secular societies. This essay tried to view of the history of interaction between Muslims and non-Muslim society in New Zealand. I was keen to explore how such businesses both inform and influence Muslim identities and community structures and redefine New Zealand sociocultural boundaries. I have located the explicit challenges of discrimination that Muslims face within the wider social context and hierarchy. The culture of adaptation employed by Muslims includes strategies of religious survival guided by both a shared notion of a collective global unity the ummah as an international religious brotherhood rather than a narrower tribal or village association-and a growing attachment and sense of allegiance to New Zealand. As we have seen in the Auckland Muslim schooling projects, Islam in this social 
hierarchy is extraordinarily complicated and multifaceted. It presents unique challenges and opportunities to New Zealand society; due to the peculiar economic, (quasi-) legal, political and social features-in addition to purely spiritual concerns-the question of how a secular country can best accommodate this faith necessitates in-depth consideration. The issue of how Muslims as individuals and private citizens can reside within New Zealand is also complicated, but less so.

The essay also tried to underline the ongoing changes that have occurred within the Muslim community structures. These serve to move beyond former ethnocultural orientations and towards a distinctly New Zealand experience of Islam. The Darwinian historical intersections of ethnicity, faith, religion, and nation in the construction of Muslim identities in New Zealand all serve to highlight how Islam ties together an ethnically heterogeneous mixture of peoples who affiliate both globally and locally. I have argued that, although not perfect, the predominantly civic orientation of New Zealand identity inherited from the British colonial era has served all citizens well and has facilitated the integration of Muslims from a variety of foreign countries. Furthermore, my text linked the ongoing discussions about the inclusive, open and tolerant nature of Anglophone New Zealand. It examined the explicit cultural, social and political aspects of the land that colour Muslim perceptions. Whilst there is room for improvement, I believe New Zealand Muslim history demonstrates that this country can serve as a model of Muslim integration for other non-Muslim societies. Both Muslims and non-Muslims here have challenged local discrimination and global stereotyping through acts of resilience and mutual engagement. The ethos of inclusion and cultural history of tolerance, both real and perceived, has made New Zealand a very successful place for comfort and belonging - a refuge where Muslims can freely articulate or manifest their visible diversity in ethnicity, faith, dietary and codes, languages, political orientation and so forth. Finally, my essay envisions a model of local pluralism predicated on free speech, capitalism, and a community tied to a set of collective civic values. Such a model is held together by the recognition of fundamental human rights and naturally located within the New Zealand tradition of justice inherited from our British colonial past. In the final analysis, this paper proposes that Biology offers History a valuable insight into human actions and motivations.

\section{REFERENCES}

Abdyli, Sabit R. Bijtë e Shqipes Në Tokën e Reve Të Bardha. Auckland: Universal Print \& Management, 2010.

Belich, James. Making Peoples: A History of the New Zealanders From Polynesian. Penguin Random House New Zealand Limited, 2007.

Bredekamp, Horst. Thomas Hobbes - Der Leviathan: Das Urbild des modernen Staates und seine Gegenbilder. 1651-2001. Walter de Gruyter, 2012.

Buang, Ahmad Hidayat. 'Islam and Muslims in New Zealand'. Jurnal Usuluddin 16 (2002): 135158.

Darwin, Charles. On the Origin of Species by Means of Natural Selection: Or the Preservation of Favoured Races in the Struggle for Life. D. Appleton, 1869. 
David, Corinne. 'Divergence and Convergence in the New Zealand Bicultural Model'. Caliban. French Journal of English Studies, no. 21 (1 May 2007): 57-66. https://doi.org/10.4000/caliban.1856.

Department, New Zealand Census and Statistics. Population Census, 1951: Religious Professions, Including Summaries for Dependent Children, Race, and War Service. R.E. Owen, Government Printer, 1953.

Drury, Abdullah. Islam in New Zealand: The First Mosque: A Short History of the New Zealand Muslim Association \& the Ponsonby Mosque. A. Drury, 2006.

. 'Mahometans on the Edge of Colonial Empire: Antipodean Experiences'. Islam and Christian-Muslim Relations 29, no. 1 (2 January 2018): 71-87. https://doi.org/10.1080/09596410.2017.1384230.

Epstein, Richard Allen. The Treaty of Waitangi: A Plain Meaning Interpretation. New Zealand Business Roundtable, 1999.

Gellner, Ernest. Nations and Nationalism. Cornell University Press, 2008.

'Islam in New Zealand'. In Wikipedia, 27 October 2020. https://en.wikipedia.org/w/index.php?title=Islam_in_New_Zealand\&oldid=9857919 76.

Kabir, Shah Nister, and Michael Bourk. 'Representing Islam and Muslims in New Zealand Newspapers'. Journal of Muslim Minority Affairs 32, no. 3 (1 September 2012): 324-38. https://doi.org/10.1080/13602004.2012.727293.

Kolig, Erich, and Nahid Kabir. 'Not Friend, Not Foe: The Rocky Road of Enfranchisement of Muslims into Multicultural Nationhood in Australia and New Zealand'. Immigrants \& Minorities 26, no. 3 (1 November 2008): 266-300. https://doi.org/10.1080/02619280802528502.

Kurt, Bayer. 'Kaumatua' of Muslims in NZ Dies Aged 87’. New Zealand Herald, 2019.

Libson, Libby. 'Kiwi Converts among New Zealand's Muslim Community'. Stuff, 13 November 2015. https://www.stuff.co.nz/life-style/life/73973867/kiwi-convertsamong-new-zealands-muslim-community.

Middleton, Sue. 'Becoming PBRF-Able: Research Assessment and Education in New Zealand'. In Assessing the Quality of Educational Research in Higher Education, 193-208. Brill Sense, 2009.

Minogue, Kenneth R. Waitangi: Morality and Reality. Wellington, N.Z: New Zealand Business Roundtable, 1998.

Mohammad, Zohoor, and Krasniqi Mazhar Shukri. One Hundred Great Muslim Leaders of the 20th Century. New Delhi: Institute of Objective Studies, 2006.

Moon, Paul. This Horrid Practice: The Myth and Reality of Traditional Maori Cannibalism. Rosedale, N.Z.; New York: Penguin Group, 2008.

Patel, Rafik. 'A Flowing Culture: Images of Early Gujarati Indian-Islamic Migrants in Aotearoa New Zealand'. Transitions: Journal of Transient Migration 1, no. 2 (1 June 2017): 251-68.

https: / go.gale.com/ps/i.do?p=AONE\&sw $=$ w\&issn $=23977140 \& v=2.1 \& i t=r \& i d=G$ ALE\%7CA489081374\&sid=googleScholar\&linkaccess=abs. 
Pratt, Douglas. 'Antipodean Angst: Encountering Islam in New Zealand'. Islam and ChristianMuslim Relations 21, no. 4 (1 October 2010): 397-407. https://doi.org/10.1080/09596410.2010.527107.

Rahman, Khairiah A., and Azadeh Emadi. 'Representations of Islam and Muslims in New Zealand Media'. Pacific Journalism Review: Te Koakoa 24, no. 2 (2018): 166-188.

Robinson, John, Bruce Moon, David Keith Round, Michael Grant Butler, Mike Butler, Hugh Barr, and Peter Cresswell (Architect). Twi\$ting the Treaty: A Tribal Grab for Wealth and Power. Tross Publishing, 2013.

Round, David. Truth Or Treaty?: Commonsense Questions about the Treaty of Waitangi. Canterbury University Press, 1998.

Scott, Stuart C. The Travesty of W aitangi: Towards Anarchy. Campbell Press, 1995.

Shepard, William. 'Erich Kolig, New Zealand's Muslims and Multiculturalism. Muslim Minorities, 9. Leiden and Boston: Brill, 2010, vi. 272 Pp. ISBN 978900417835 9'. Contemporary Islam 6, no. 2 (1 July 2012): 205-7. https://doi.org/10.1007/s11562-0100143-6.

. 'NEW ZEALAND'S MUSLIMS AND THEIR ORGANISATIONS'. New Zealand 8, no. 2 (2006): 37.

Smith, Anthony D. 'Book Review: Ernest Gellner, Nations and Nationalism (Oxford: Basil Blackwell, 1983, 150pp., £12.50 Hardback, £4.95 Paperback)’. Millennium 12, no. 3 (1 September 1983): 280-82. https://doi.org/10.1177/03058298830120030804.

Thomson, Ainsley. 'Mazhar Krasniqi”. New Zealand Herald, 2002. 